This is an electronic reprint of the original article. This reprint may differ from the original in pagination and typographic detail.

Author(s): Beyeh, Ngong Kodiah; Jo, Hyun Hwa; Kolesnichenko, Igor; Pan, FangFang; Kalenius, Elina; Anslyn, Eric Van; Ras, Robin H. A.; Rissanen, Kari

Title: $\quad$ The Recognition of Viologen Derivatives in Water by N-Alkyl Ammonium Resorcinarene Chlorides

Year: $\quad 2017$

Version:

Please cite the original version:

Beyeh, N. K., Jo, H. H., Kolesnichenko, I., Pan, F., Kalenius, E., Anslyn, E. V., Ras, R. H. A., \& Rissanen, K. (2017). The Recognition of Viologen Derivatives in Water by N-Alkyl Ammonium Resorcinarene Chlorides. Journal of Organic Chemistry, 82(10), 51985203. https://doi.org/10.1021/acs.joc.7b00449

All material supplied via JYX is protected by copyright and other intellectual property rights, and duplication or sale of all or part of any of the repository collections is not permitted, except that material may be duplicated by you for your research use or educational purposes in electronic or print form. You must obtain permission for any other use. Electronic or print copies may not be offered, whether for sale or otherwise to anyone who is not an authorised user. 


\section{The Journal of Organic Chemistry}

Subscriber access provided by JYVASKYLAN UNIV

\section{Article}

\section{The Recognition of Viologen Derivatives in Water by N-Alkyl Ammonium Resorcinarene Chlorides}

Ngong Kodiah Beyeh, Hyun Hwa Jo, Igor Kolesnichenko, FangFang Pan, Elina Kalenius, Eric Van Anslyn, Robin H. A. Ras, and Kari Rissanen

J. Org. Chem., Just Accepted Manuscript • Publication Date (Web): 28 Apr 2017

Downloaded from http://pubs.acs.org on May 2, 2017

\section{Just Accepted}

"Just Accepted" manuscripts have been peer-reviewed and accepted for publication. They are posted online prior to technical editing, formatting for publication and author proofing. The American Chemical Society provides "Just Accepted" as a free service to the research community to expedite the dissemination of scientific material as soon as possible after acceptance. "Just Accepted" manuscripts appear in full in PDF format accompanied by an HTML abstract. "Just Accepted" manuscripts have been fully peer reviewed, but should not be considered the official version of record. They are accessible to all readers and citable by the Digital Object Identifier (DOI®). "Just Accepted" is an optional service offered to authors. Therefore, the "Just Accepted" Web site may not include all articles that will be published in the journal. After a manuscript is technically edited and formatted, it will be removed from the "Just Accepted" Web site and published as an ASAP article. Note that technical editing may introduce minor changes to the manuscript text and/or graphics which could affect content, and all legal disclaimers and ethical guidelines that apply to the journal pertain. ACS cannot be held responsible for errors or consequences arising from the use of information contained in these "Just Accepted" manuscripts. 


\section{INTRODCUTION}

Molecular receptors with pre-organized cavities suitable for guest recognition is a continuously developing area in supramolecular chemistry, material science, and biology. ${ }^{1,2}$. Receptors capable of guest recognition in aqueous media and biological fluids have a growing importance, relative to receptors that primarily function in organic media. ${ }^{3-6}$ However, receptors that can operate in aqueous media have proven to be difficult to design. ${ }^{7-12}$ However, they have potential biocompatibility if one can exploit the cohesive force of water. ${ }^{3-6}$

Viologen (1,1'-disubstituted-4,4'-bipyridine salts) materials are well known for their strong redox properties. ${ }^{13}$ Viologens, with their extended $\pi$-conjugation, can exhibit excellent electrochromic and photochromic properties. ${ }^{14-16}$ These species are commonly used in supramolecular chemistry to construct capsular assemblies or threaded structures with several host compounds. ${ }^{17-21}$ Their cationic nature makes them suitable guests for $\pi$-rich receptors. ${ }^{17-21}$ The complexation of viologen derivatives, by receptors such as curcubiturils, can substantially alter the kinetics and thermodynamics of their electron transfer reactions. ${ }^{17,18}$ Modified viologens have potential as sensors for bisulfite in water which can be utilized in the beverage industry. ${ }^{22-25}$

$N$-Alkyl ammonium resorcinarene halides (NARXs), resulting from the ring opening of tetrabenzoxazines in the presence of mineral acids under refluxing conditions, are stabilized by a seam of hydrogen-bonded cation-anion interactions. $^{26,27}$ The NARX receptors possess four spatially fixed halide anions with deep cavities for guest binding. Neutral and anionic guests have been shown to reside in the cavity of NARXs, interacting with the host mainly through 
$\mathrm{CH}-\pi$ interactions and hydrogen bonds. ${ }^{28,29}$ We recently reported the binding of small neutral molecules such as amides and diamides in organic media with cooperativity by NARX receptors. ${ }^{30}$ The four spatially fixed anions act as halogen bond acceptors leading to a variety of complex architectures, such as deep-cavity cavitands, pseudo-capsular, and capsular assemblies. ${ }^{31,32}$ The NARXs are generally soluble in alcoholic and non-polar solvents. Recently we synthesized the first water soluble NARX receptors by attaching terminal hydroxyl groups at the upper rim. ${ }^{33}$ Therein, we showed that the water soluble NARXs exist in $\mathrm{C}_{4 v}$ crown conformation and bind a variety of aliphatic, aromatic and halogenated alkanes and arenes in aqueous media. ${ }^{33}$

In this study, three new water-soluble $\mathrm{NARCl}$ receptors decorated with four terminal hydroxyl groups at the lower rims were synthesized and characterized (Figure 1). The first NARCl receptor (5), is also functionalized at the upper rim with four terminal hydroxyl groups, making it extremely water soluble $(35 \mathrm{mg} / \mathrm{mL})$. The receptor (7) is functionalized at the upper rim with four rigid cyclohexyl groups and the third receptor (9) possesses four flexible benzyl groups at the upper rim. Mono-methyl 4,4'-bipyridine (11) ${ }^{34}$ mono-acetylmethyl 4,4'-bipyridine (12), and hetero methyl-acetylmethyl 4,4'bipyridine (13) molecules were also synthesized as potential guests. The recognition of these guests (11-13) by the NARX receptors $(\mathbf{5}, \mathbf{7}$ and $\mathbf{9})$ were investigated in water via ${ }^{1} \mathrm{H}$ NMR spectroscopy, fluorescence spectroscopy, and isothermal titration calorimetry (ITC) analyses.

\section{RESULTS AND DISCUSSION}

Synthesis of the receptors and the viologen guests. The synthesis of 5, 7 and 9 starts with resorcinarene $\mathbf{3}$, which was synthesized through reported procedures. ${ }^{35}$ Ethanolamine, cyclohexyl amine and benzyl amine in the presence of excess formaldehyde participate in a Mannich condensation with $\mathbf{3}$ to form tetrabenzoxazines 4, $\mathbf{6}$ and $\mathbf{8}$, respectively. ${ }^{36,37}$ The reaction with ethanolamine leads to a mixture of the five and six membered azoxazine rings $\mathbf{4 a}$ and $\mathbf{4 b}$, respectively. The un-isolated crude product containing the five- and six-membered ring compounds in the presence of concentrated $\mathrm{HCl}$ under refluxing conditions, lead to the same final product 5 (Figure 1). Cleavage of the pure tetrabenzoxazines 6 and 8 under similar conditions give NARCls $\mathbf{7}$ and $\mathbf{9}$. The detailed synthetic procedures of the NARCl receptors are reported in the Supporting Information (Schemes S1-S3; Figures S1-S5). 


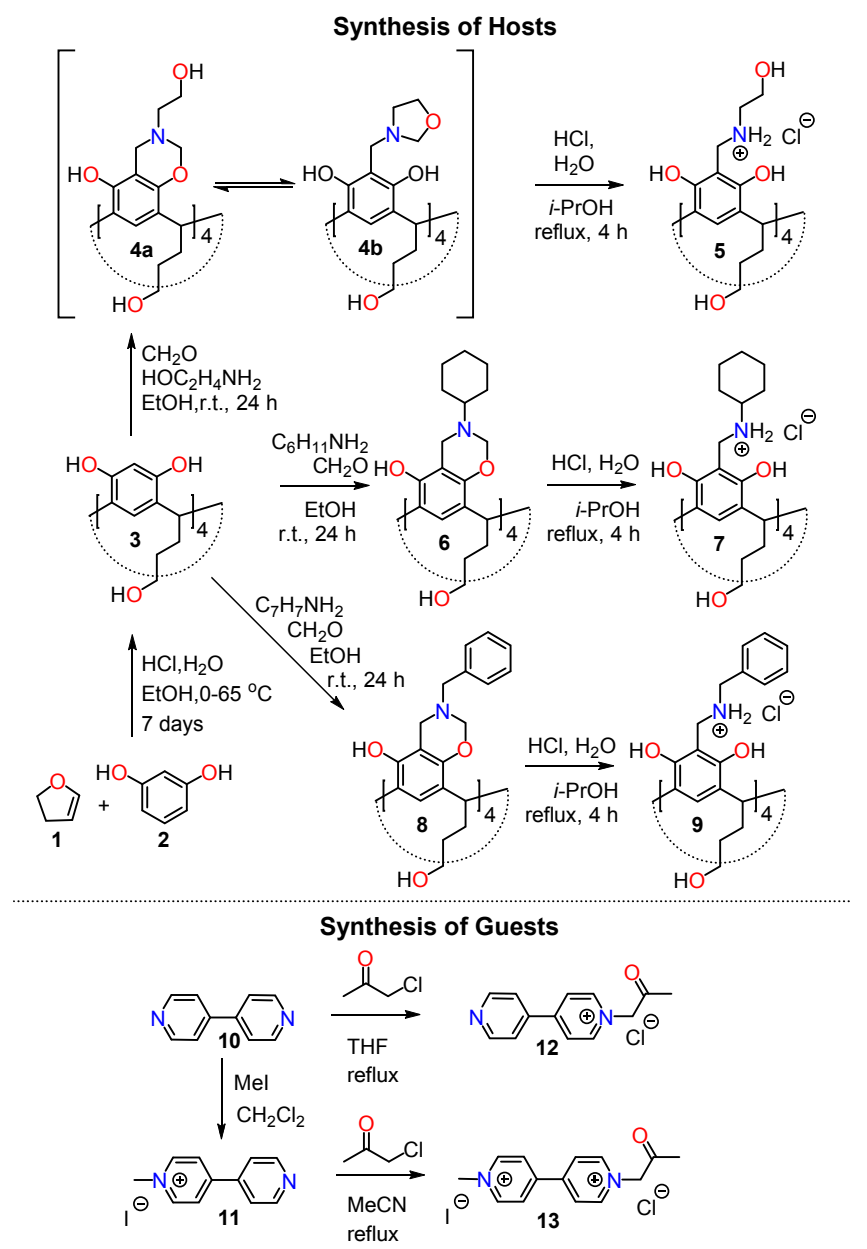

Figure 1. Synthesis of water soluble NARCls 5, 7 and $\mathbf{9}$ as receptors and derivatives of 4,4'-bipyridine 11-13 as guests.

The 4,4'-bipyridine guest $\mathbf{1 1}$ was synthesized according to a reported procedure. ${ }^{34}$ The other bipyridine guests, $\mathbf{1 2}$ and $\mathbf{1 3}$, were synthesized by reacting chloroacetone with 4,4'-bipyridine or guest 11, respectively (Schemes S4, S5; Figures S6S8). Suitable single crystals of mono-methyl 4,4'-bipyridine (11) and hetero- methyl-acetylmethyl 4,4-bipyridine (13) were obtained and analyzed (Figures S9-S11). Structural analysis verified the bipyridine was successfully substituted. In 11, the $N$-methyl 4,4'-bipyridyl cation is paired with the iodide anion with the anion close to the cationic nitrogen of the viologen molecule. While in $\mathbf{1 3}$, although the dicationic viologen is as expected, the original counter anions are replaced by $1.5 \mathrm{I}^{-}$and $0.5 \mathrm{I}_{3}^{-}$during the crystallization. Electrostatic forces contribute to the arrangement of the ion pairs. A mechanism for formation of the triiodide from iodide was proposed in a recent crystallographic study. ${ }^{38}$

Hydrogen/Deuterium (H/D) Exchange Studies of the Viologen Guests. In $\mathrm{D}_{2} \mathrm{O}$, the labile $-\mathrm{NCH}_{2} \mathrm{CO}-$ hydrogens undergo H/D exchange. These protons are therefore not observed in the ${ }^{1} \mathrm{H}$ NMR spectra of all samples containing guests 12 and $\mathbf{1 3}$ in protic deuterated solvents. The lability of these hydrogens was verified by electrospray ionization mass spectrometry (ESI-MS) in a combined experiment of solution H/D-exchange and collision induced dissociation (CID). In $\mathrm{D}_{2} \mathrm{O}$ (Figure 2, Figures. S12, S13), two H/D-exchanges of $-\mathrm{NCH}_{2} \mathrm{CO}$ - hydrogens were observed. The location of exchanged hydrogens was verified by CID experiment, which showed the fragmentation to be initiated by elimination of undeuterated acetyl radical $\left(\mathrm{C}_{2} \mathrm{H}_{3} \mathrm{O}^{\circ}, 43 \mathrm{u}\right)$, leaving only one plausible location for $\mathrm{H} / \mathrm{D}$-exchange at -NCH $\mathrm{CO}_{2}$-. The CID experiments also showed the increased stability of keto tautomer as compared to possible enol form. This is likely due to existence of two resonance structures of keto tautomer (see SI, Figure S12). 

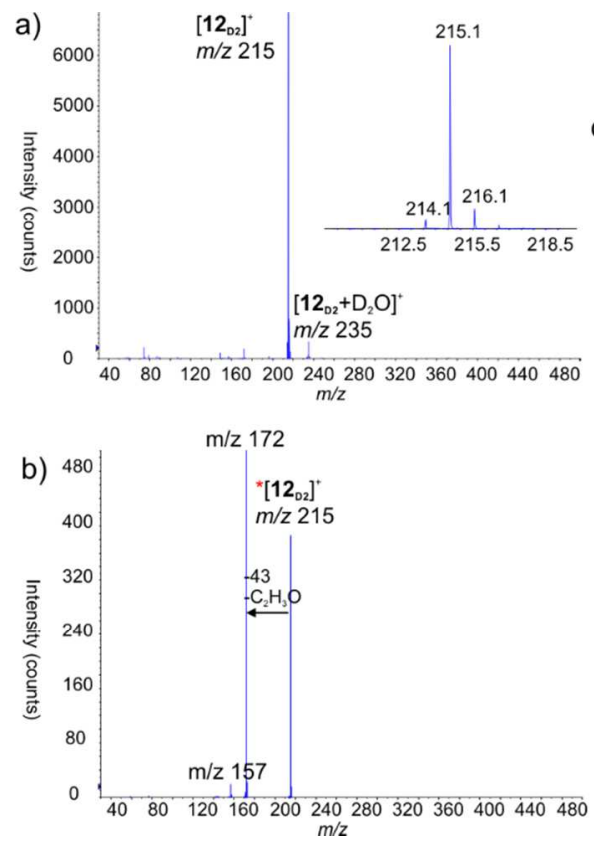

c)

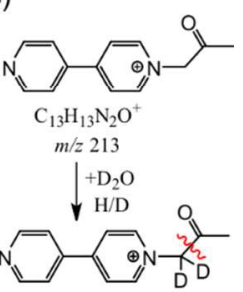

$\mathrm{C}_{13} \mathrm{H}_{11} \mathrm{D}_{2} \mathrm{~N}_{2} \mathrm{O}^{+}$ $m / 2215$ $-1-\sqrt{-43 \mathrm{u}=\mathrm{C}_{2} \mathrm{H}_{3} \mathrm{O}}$

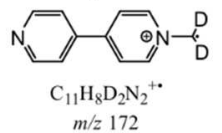

Figure 2. ESI-MS of 12 in $\mathrm{D}_{2} \mathrm{O}$. (a) Profile spectrum showing two H/D-exchanges, inset showing zoomed view for $m / z$ 215. (b) CID for isolated $\left[\mathbf{1 2}_{\mathrm{D} 2}\right]^{+}$ion $(\mathrm{CE}=29)$. (c) Main fragmentation pathway for ion $\left[\mathbf{1 2}_{\mathrm{D} 2}\right]^{+}$.

Complexation Studies via NMR Spectroscopy. Complexation studies between the NARCl receptors (5, 7 and 9) with the modified 4,4-bipyridine guests (11-13) were investigated by ${ }^{1} \mathrm{H}$ NMR experiments in $\mathrm{D}_{2} \mathrm{O}$. The receptors possess $\mathrm{C}_{4} v$ symmetry in solution as observed from their relatively simple ${ }^{1} \mathrm{H}$ NMR spectra (Figures S1, S3 and S5). Varying complexation-induced shift changes of the different guest signals were observed from either the shielding effects of the aromatic rings of the bowl-shaped host cavity or interaction with the cation-anion seam. The complexation process is fast on the NMR time scale at $298 \mathrm{~K}$. The guests are soluble in water and can interact with the hosts mainly through $\mathrm{CH}-\pi$ and hydrogen bond interactions with the cation-anion seam of the receptors. The small shift changes of the guests can be attributed to the highly competitive nature of the bulk water. Taking the complex 13@7 as an example, upfield shifts of the guest $-\mathrm{COCH}_{3}$ - protons are observed (Figure 3). The carbonyl oxygens are known to interact with the cation-anion seam in organic media as reported in the binding of amides by NARXs. ${ }^{30}$ Upfield shift of methyl protons of ammonium cations are usually observed when located deep in the cavity of resorcinarene-type receptors. The relatively small upfield shifts of the methyl protons of guest $\mathbf{1 3}$ therefore suggest the binding interaction to occur mainly at the upper rim of the receptors involving the hydrogen-bonded cation-anion seam with minimal interaction with the electron rich interior cavity of the resorcinarene cavity (Figure 3).

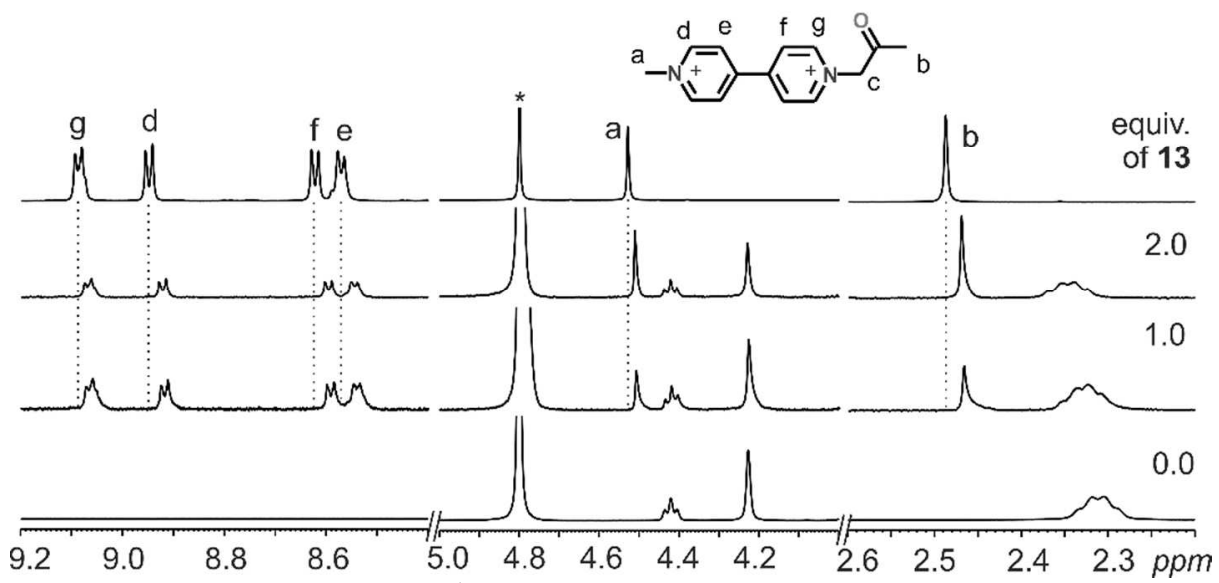

Figure 3. Selected region of the ${ }^{1} \mathrm{H}$ NMR (400 MHz, $\left.\mathrm{D}_{2} \mathrm{O}, 298 \mathrm{~K}\right)$ spectra observed upon the addition of the guest 13 to the host 7 . Dotted lines gives an indication of the complexation induced shift changes. 
The ${ }^{1} \mathrm{H}$ NMR spectra of the 1:1 mixture between the guests $\mathbf{1 1}$ and $\mathbf{1 2}$ reveal mainly downfield shifts of the guests signals (Figures S15-S20). Limited and/or no shift changes were observed for the guests methyl signals. This again suggest the interaction between the guests $\mathbf{1 1}$ and $\mathbf{1 2}$ with the receptors to be mainly at the upper rim of the receptors involving the hydrogen-bonded cation-anion seam of the receptors and the free pyridine nitrogens of the guests (Figures S15-S22). Such hydrogen bond interactions between the pyridine nitrogen of the guests (11 and 12) leads to de-shielding contrary to the guest 13 with no free pyridine nitrogen.

Quantification of the Binding Process via Isothermal Titration Calorimetry (ITC) Studies. The interaction between the hosts and guests was quantified through a series of ITC experiments in $\mathrm{H}_{2} \mathrm{O}$ (Figure 4, Figures S23, S24). The thermodynamic parameters of host-guest binding $(K, \Delta H, \Delta S$, and $\Delta G)$ were extracted from fitting to a single binding site model (Table 1). When comparing the ITC titrations of the three NARCl receptors $(\mathbf{5 , 7}$ and $\mathbf{9})$ with the guests (11-13), several considerations can be made. The $\Delta H$ and $\Delta G$ values indicate the binding process to be exothermic and spontaneous at $298 \mathrm{~K} . \Delta H$ and $T \Delta S$ results also indicate that complexation of guests 11-13 by the receptors to be both enthalpy and entropy driven in most cases. In three cases $(11 @ 5,13 @ 5,13 @ 9)$, negative $\Delta S$ values indicate these process to be enthalpy driven.
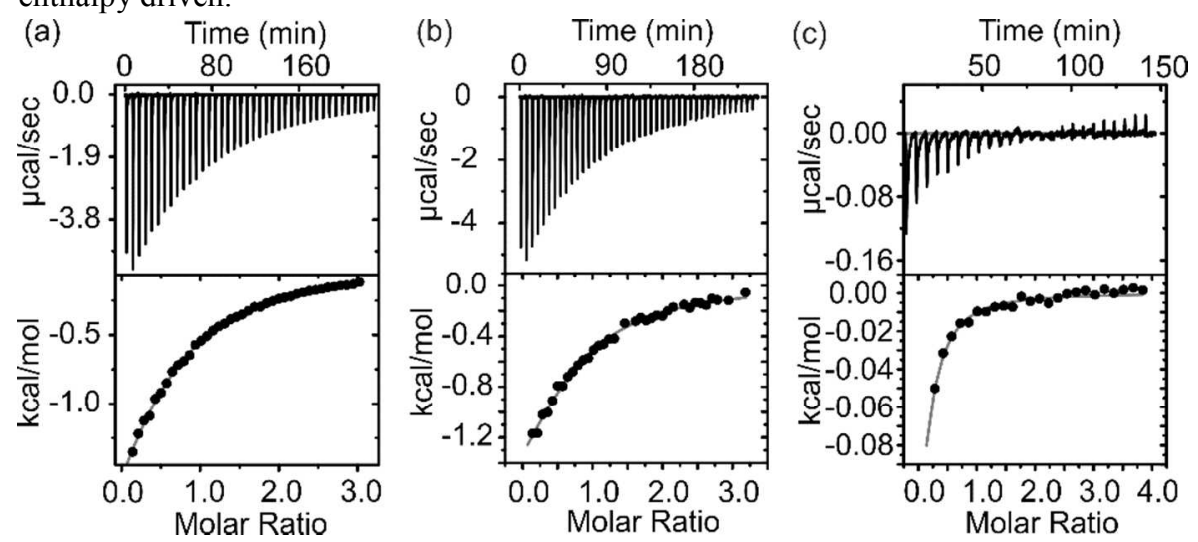

Figure 4. ITC traces of the titration of guests $(10 \mathrm{mM})$ into host $7(1 \mathrm{mM})$ in $\mathrm{H}_{2} \mathrm{O}$ at $298 \mathrm{~K}$. (a) guest 11, (b) guest 12, (c) guest 13. All data were fitted into a one site-model.

Table 1. Thermodynamic binding parameters of formed complexes between the hosts 5,7 $(10 \mathrm{mM})$ and the guests 9-11 $(1 \mathrm{mM})$ by ITC ${ }^{[a]}$

\begin{tabular}{ccclc}
\hline Complex & $\begin{array}{c}K\left(\times 10^{3}\right) \\
{\left[\mathrm{M}^{-1}\right]}\end{array}$ & $\begin{array}{c}\Delta H \\
{[\mathrm{kcal} / \mathrm{mol}]}\end{array}$ & $\begin{array}{c}T \Delta S \\
{[\mathrm{kcal} / \mathrm{mol}]}\end{array}$ & $\begin{array}{c}\Delta G \\
{[\mathrm{kcal} / \mathrm{mol}]}\end{array}$ \\
\hline $\mathbf{1 1 @ 5}$ & $0.91 \pm 0.09$ & -8.698 & -4.657 & -4.041 \\
$\mathbf{1 1 @ 7}$ & $1.17 \pm 0.04$ & -4.085 & 0.103 & -4.188 \\
$\mathbf{1 1 @ 9}$ & $0.95 \pm 0.02$ & -3.422 & 0.644 & -4.066 \\
$\mathbf{1 2 @ 5}$ & $2.29 \pm 0.30$ & -1.686 & 2.896 & -4.582 \\
$\mathbf{1 2 @ 7}$ & $1.49 \pm 0.14$ & -2.602 & 1.728 & -4.330 \\
$\mathbf{1 2 @ 9}$ & $1.05 \pm 0.09$ & -3.595 & 0.527 & -4.122 \\
$\mathbf{1 3 @ 5}$ & $1.70 \pm 0.50$ & -25.01 & -20.58 & -4.422 \\
$\mathbf{1 3 @ 7}$ & $2.78 \pm 0.83$ & -0.567 & 4.130 & -4.697 \\
$\mathbf{1 3 @ 9}$ & $1.37 \pm 0.14$ & -45.970 & -41.660 & -4.310 \\
\hline
\end{tabular}

${ }^{[\mathrm{a}]} \mathrm{ITC}$ in $\mathrm{H}_{2} \mathrm{O}$ at $298 \mathrm{~K}$.

Complexation Studies via Fluorescence Spectroscopic Analysis. We also used optical titrations to analyze the binding processes. Fluorescence enhancement and/or quenching were observed from titration experiments conducted at $298 \mathrm{~K}$ with solutions of the hosts 5, 7 and the guests 11-13. A solution of the guests $(0.1 \mathrm{M})$ at $298 \mathrm{~K}$ was titrated into a solution of the hosts 5 and $7(2 \mathrm{~mL}, 125 \mu \mathrm{M})$. In all cases, fluorescence spectra were collected after thermal equilibration at $298 \mathrm{~K}$ (Figure 5, Figure S25-S29). 


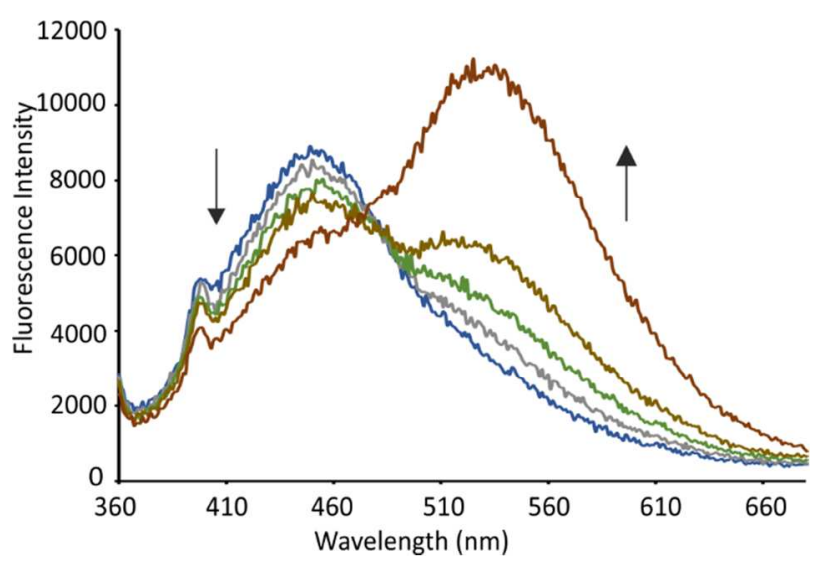

Figure 5. Fluorescence changes of guest $13(0.1 \mathrm{M})$ when titrated to host $7(125 \mu \mathrm{M}, 2 \mathrm{~mL})$ in $\mathrm{H}_{2} \mathrm{O}$ at $298 \mathrm{~K}$. Total of 4 additions of guest $\mathbf{1 3}(0.4,1.0,2.0,8.0$ equiv. $)$ were added to host 7 .

The red shift in fluorescence emission spectra of the guest 13, registering two maximum (458 nm and $545 \mathrm{~nm}$ ), was observed. The lack of a clear isosbestic point indicates that there are more than two species in the system, which is hypothesized to be the formation of aggregates due to the high concentration of guests used in the system. Fluorescence enhancement was observed for the guests during the titration with the hosts $\mathbf{5}$ and $\mathbf{7}$. The excited-state vibrational dynamics of the viologen guests 11-13 appears to play the key role in the observed enhancement, as well as the red shift of the emission when the viologens concentration is increased. Studies by Galoppini and coworkers, ${ }^{39}$ and Pal and coworkers, ${ }^{40}$ show similar behavior of a viologen and the dye Brilliant Green, a triphenylmethane derivative, where restriction of intramolecular bond rotations between the aryl rings induced by complexation/encapsulation with cucurbiturils resulted in enhanced fluorescence.

\section{CONCLUSION}

In conclusion, we synthesized three water-soluble NARCl receptors $(\mathbf{5 , 7}$ and $\mathbf{9})$ with varying hydrophilicity of the upper rim substituents. These receptors exists in the $C_{4 v}$ bowl-shaped conformation as observed from their relatively simple ${ }^{1} \mathrm{H}$ NMR spectra. The binding properties of the NARCl receptors and three water-soluble viologen derivatives (11-13) were investigated in water via NMR, ITC, and fluorescence studies. Binding constants of $10^{3} \mathrm{M}^{-1}$ were observed via ITC analyses. The hosts show higher affinity towards the acetylmethyl-derived viologen guests $\mathbf{1 2}$ and $\mathbf{1 3}$ over the methyl viologen derivative 11. The higher affinity can be attributed to hydrogen bond interactions between the host cation-anion seam and the guest carbonyl groups. This study illustrates the versatility of the NARXs, which in water possesses hydrophobic cavities and hydrophilic cation-anion seam. The ease of functionalization of resorcinarene type receptors into water soluble NARCl receptors make resorcinarenes a very interesting class of receptor compounds. This versatility renders the NARXs as suitable receptors for a variety of guests in water.

\section{EXPERIMENTAL SECTION}

General Methods. The $N$-alkyl ammonium resorcinarene chlorides 5, 7 and 9 were synthesized accordingly to modified procedures. ${ }^{26,27,36}{ }^{1} \mathrm{H}$ and ${ }^{13} \mathrm{C}$ NMR spectra were recorded on a Bruker Avance DRX $500\left(500 \mathrm{MHz}\right.$ for ${ }^{1} \mathrm{H}$ and $126 \mathrm{MHz}$ for $\left.{ }^{13} \mathrm{C}\right)$ and DRX $400\left(400 \mathrm{MHz}\right.$ for ${ }^{1} \mathrm{H}$ and $100 \mathrm{MHz}$ for $\left.{ }^{13} \mathrm{C}\right)$ spectrometers. All signals are given as $\delta$ values in ppm using residual solvent signals as the internal standard. Coupling constants are given in Hz. Melting points were determined with a Mettler Toledo FP62 capillary melting point apparatus and a Stuart SMP30 melting point apparatus. Experimental details for the synthesis and characterization data of receptors 5, 6, 7, 8 and 9 , and guests 12 and 13 are below. Compounds 3, and $\mathbf{1 1}$ are known compounds and have been reported in previous references. ${ }^{34,35,41}$ Mass spectrometry experiments were performed with ABSciex QSTAR Elite ESI-Q-TOF mass spectrometer, equipped with an API 200 TurboIonSpray ESI source from AB Sciex. Nitrogen was used as drying and nebulization gas. VP-ITC instrument made by MicroCal were used to determine the molar enthalpy $(\Delta H)$ of complexation. Subsequent fitting of the data to a $1: 1$ binding model using Origin software provides binding constant $(\mathrm{K})$ and the entropy $(\Delta \mathrm{S})$. Fluorescence spectra were recorded on a PTI QuantaMasterTM 40 intensity based spectrofluorometer equipped with 814 photomultiplier detection system (V=1000 volts). A $75 \mathrm{~W}$ Xenon arc lamp was used as the excitation source. The data for crystals of 11, 11b, and $\mathbf{1 3}$ were collected at $123 \mathrm{~K}$ for $\mathbf{1 1 b}$ with an Agilent Super-Nova diffractometer using mirror-monochromatized $\mathrm{Cu}-\mathrm{K \alpha}(\lambda=1.54184 \AA)$ radiation, and at $100 \mathrm{~K}$ for $\mathbf{1 1}$ and 13 with the same diffractometer using mirror-monochromatized Mo- $K \alpha(\lambda=0.71073 \AA)$ radiation. 
General procedure for the synthesis of tetrabenzoxazines from the resorcinarene 3. To a solution of the resorcinarene 3 (5.5 mmols) and excess formaldehyde $(6 \mathrm{~mL})$ in ethanol $(40 \mathrm{~mL})$, the amine $(23.3 \mathrm{mmols})$ in ethanol $(15$ $\mathrm{mL}$ ) is added slowly and stirred at room temperature for $24 \mathrm{~h}$. The precipitate that separated is filtered, recrystallized in a methanol/n-hexane mixture and dried.

General procedure for the synthesis of the $\mathrm{N}$-alkyl ammonium resorcinarene chlorides from the tetrabenzoxazines. Into a solution of the tetrabenzoxazine $(0.82 \mathrm{mmol}), 3 \mathrm{~mL}$ concentrated $\mathrm{HCl}(37 \%)$ and $4 \mathrm{ml} \mathrm{H}_{2} \mathrm{O}$ in $50 \mathrm{ml}$ isopropanol is heated under reflux. Water and formaldehyde are removed by azeotropic distillation with chloroform. The remaining isopropanol is evaporated and the crude product triturated with diethyl ether to give the $N$-alkyl ammonium resorcinarene chloride.

$N$-Ethanol ammonium resorcinarene chloride (5): $C_{\text {propanol }}$-Resorcinarene 3 (4 g, 7.344 mmols), formaldehyde (8 mL), EtOH $(60 \mathrm{~mL}), 2$-aminoethanol $(1.86 \mathrm{~mL}, 30.8 \mathrm{mmols})$, EtOH $(15 \mathrm{ml})$. The product was a mixture of the six-membered and five-membered tetrabenzoxazines $\mathbf{4 a} / \mathbf{4 b}$. This mixture of tetrabenzoxazines was not separated and was used directly in the next step to obtain the $N$-Ethanol ammonium resorcinarene chloride $\mathbf{5}$. The crude tetrabenzoxazines $\mathbf{4 a} / \mathbf{4} \mathbf{b}(1.0 \mathrm{~g}, 1.129$ mmol), $3 \mathrm{ml}$ conc. $\mathrm{HCl}, 4 \mathrm{ml} \mathrm{H} \mathrm{H}_{2}, 40 \mathrm{ml}$ isopropanol. $N$-Ethanol ammonium resorcinarene chloride 5 (0.68 g, 61 \%). m.p. $>300{ }^{\circ} \mathrm{C}$; HRMS (ESI-TOF) $\mathrm{m} / \mathrm{z}$ calcd for $\mathrm{C}_{52} \mathrm{H}_{77} \mathrm{~N}_{4} \mathrm{O}_{16}$ [5-4Cl-3H] ${ }^{+}$1013.5329, Found 1013.5331, (-0.2 ppm);. ${ }^{1} \mathrm{H}$ NMR $\left(400 \mathrm{MHz}, 298 \mathrm{~K}\right.$ in $\left.\mathrm{CD}_{3} \mathrm{OD}\right) \delta(\mathrm{ppm}): 1.53\left(\mathrm{~m}, 8 \mathrm{H}, \mathrm{CH}_{2}\right), 2.39\left(\mathrm{~m}, 8 \mathrm{H}, \mathrm{CH}_{2}\right), 3.04\left(\mathrm{t}, \mathrm{J}=5.06 \mathrm{~Hz}, 8 \mathrm{H}, \mathrm{OCH}_{2}\right), 3.66(\mathrm{t}$, $\left.\mathrm{J}=6.20 \mathrm{~Hz}, 8 \mathrm{H}, \mathrm{NCH}_{2}\right), 3.78\left(\mathrm{t}, \mathrm{J}=5.12 \mathrm{~Hz}, 8 \mathrm{H}, \mathrm{OCH}_{2}\right), 4.32\left(\mathrm{~s}, 8 \mathrm{H}, \mathrm{ArCH}_{2} \mathrm{~N}\right), 4.47(\mathrm{t}, \mathrm{J}=7.80 \mathrm{~Hz}, 4 \mathrm{H}, \mathrm{CH}), 7.48(\mathrm{~s}, 4 \mathrm{H}$, ArH); ${ }^{13} \mathrm{C}$ NMR: $\left(100 \mathrm{MHz}, 298 \mathrm{~K}\right.$ in $\left.\mathrm{D}_{2} \mathrm{O}\right) \delta(\mathrm{ppm})=30.9,32.0,35.8,42.6,57.6,62.7,110.2,126.7,128.1,151.9$.

$N$-Cyclohexyl Tetrabenzoxazine (6): $C_{\text {propanol }}$-Resorcinarene (4 g, $\left.5.5 \mathrm{mmols}\right)$, formaldehyde $(6 \mathrm{~mL})$, ethanol $(40 \mathrm{~mL})$, cyclohexyl amine $(2.31 \mathrm{~mL}, 23.3 \mathrm{mmols})$, ethanol $(15 \mathrm{~mL})$. Tetrabenzoxazine $6\left(5.29 \mathrm{~g}, 79\right.$ \%). m.p. 218-220 ${ }^{\circ} \mathrm{C}$; HRMS (ESI-TOF) $\mathrm{m} / \mathrm{z}$ calcd for $\mathrm{C}_{72} \mathrm{H}_{101} \mathrm{~N}_{4} \mathrm{O}_{12}[\mathbf{6}+\mathrm{H}]^{+} 1213.7411$, Found 1213.7422, $(-0.9 \mathrm{ppm}) ; .{ }^{1} \mathrm{H}$ NMR $(400 \mathrm{MHz}, 298 \mathrm{~K}$ in [D $\left.\left.\mathrm{D}_{6}\right] \mathrm{DMSO}\right) \delta(\mathrm{ppm}): 0.98-1.92\left(\mathrm{~m}, 48 \mathrm{H}, \mathrm{CH}_{2}\right), 2.24\left(\mathrm{~m}, 8 \mathrm{H}, \mathrm{CH}_{2}\right), 2.43\left(\mathrm{~m}, 8 \mathrm{H}, \mathrm{CH}_{2}\right), 3.44\left(\mathrm{q}, \mathrm{J}=4.96 \mathrm{~Hz}, 8 \mathrm{H}, \mathrm{OCH}_{2}\right)$, $3.77\left(\mathrm{dd}, 8 \mathrm{H}, \mathrm{Ar}-\mathrm{CH}_{2}-\mathrm{N}\right), 4.08\left(\mathrm{t}, \mathrm{J}=7.94 \mathrm{~Hz}, 4 \mathrm{H}, \mathrm{OCH}_{2}\right.$ ), 4.32 (t, J=4.90 Hz, 4H, OH), 5.06 (dd, J=9.64 Hz, 8H, Ar-CH ${ }_{2}^{-}$ O), 7.40 (s, 4H, Ar-H), 7.62 (s, 4H, Ar-OH); ${ }^{13} \mathrm{C}$ NMR: (100 MHz, $298 \mathrm{~K}$ in [D6]DMSO) $\delta(\mathrm{ppm})=24.2,24.8,24.9,25.4$, 29.0, 30.3, 31.0, 31.8, 32.0, 42.9, 57.1, 60.4, 60.5, 80.3, 108.6, 122.1, 123.4, 123.8, 148.6.

$\mathrm{N}$-Cyclohexyl ammonium resorcinarene chloride (7): Tetrabenzoxazine $6(1.0 \mathrm{~g}, 0.824 \mathrm{mmol}), 3 \mathrm{~mL}$ concentrated $\mathrm{HCl}$ (37\%), $4 \mathrm{ml} \mathrm{H} \mathrm{H}_{2} \mathrm{O}, 50 \mathrm{ml}$ isopropanol, $N$-Cyclohexyl ammonium resorcinarene chloride $7(1.00 \mathrm{~g}, 92 \%)$. m.p. $>300^{\circ} \mathrm{C}$; HRMS (ESI-TOF) $\mathrm{m} / \mathrm{z}$ calcd for $\mathrm{C}_{68} \mathrm{H}_{101} \mathrm{~N}_{4} \mathrm{O}_{12}[7-4 \mathrm{Cl}-3 \mathrm{H}]^{+} 1165.7411$, Found $1165.7396,(1.3 \mathrm{ppm}) .{ }^{1} \mathrm{H}$ NMR (500 MHz, $298 \mathrm{~K}$ in $\left.\mathrm{D}_{2} \mathrm{O}\right) \delta(\mathrm{ppm}): 0.88\left(\mathrm{~m}, 12 \mathrm{H}, \mathrm{CH}_{2}\right), 1.11\left(\mathrm{~m}, 12 \mathrm{H}, \mathrm{CH}_{2}\right), 1.45\left(\mathrm{~m}, 12 \mathrm{H}, \mathrm{CH}_{2}\right), 1.56\left(\mathrm{~d}, \mathrm{~J}=13.00 \mathrm{~Hz}, 8 \mathrm{H}, \mathrm{CH}_{2}\right), 1.79$ $\left(\mathrm{d}, \mathrm{J}=9.50 \mathrm{~Hz}, 8 \mathrm{H}, \mathrm{CH}_{2}\right), 2.26\left(\mathrm{~m}, 8 \mathrm{H}, \mathrm{CH}_{2}\right), 2.68(\mathrm{~m}, 4 \mathrm{H}, \mathrm{NCH}), 3.61\left(\mathrm{t}, \mathrm{J}=6.45 \mathrm{~Hz}, 8 \mathrm{H}, \mathrm{OCH}_{2}\right), 4.20\left(\mathrm{~s}, 8 \mathrm{H}, \mathrm{Ar}_{-} \mathrm{CH}_{2}-\mathrm{N}\right)$, $4.38(\mathrm{t}, \mathrm{J}=7.77 \mathrm{~Hz}, 4 \mathrm{H}, \mathrm{CH}), 7.38(\mathrm{~s}, 4 \mathrm{H}, \mathrm{Ar}-\mathrm{H}) ;{ }^{13} \mathrm{C}$ NMR: $\left(126 \mathrm{MHz}, 298 \mathrm{~K}\right.$ in $\left.\mathrm{D}_{2} \mathrm{O}\right) \delta(\mathrm{ppm})=14.0,23.8,24.2,28.7$, $29.5,29.7,34.2,38.6,56.5,61.5,65.9,109.0,125.3,126.9,150.1$.

$N$-Benzyl Tetrabenzoxazine (8): $C_{\text {propanol }}$-Resorcinarene $(5 \mathrm{~g}, 6.9 \mathrm{mmols})$, formaldehyde $(10 \mathrm{~mL})$, ethanol $(60 \mathrm{~mL})$, benzyl amine (3.18 mL, 29.0 mmols), ethanol $(15 \mathrm{~mL})$. Tetrabenzoxazine 8 ( $4.74 \mathrm{~g}, 55 \%$ ). m.p. $179-181{ }^{\circ} \mathrm{C}$; HRMS (ESITOF) $\mathrm{m} / \mathrm{z}$ calcd for $\mathrm{C}_{76} \mathrm{H}_{85} \mathrm{~N}_{4} \mathrm{O}_{12}[\mathbf{8}+\mathrm{H}]^{+}$1245.6159, Found 1245.6133, (2.1 ppm). ${ }^{1} \mathrm{H}$ NMR $(400 \mathrm{MHz}, 298 \mathrm{~K}$ in $\left.\left[\mathrm{D}_{6}\right] \mathrm{DMSO}\right) \delta(\mathrm{ppm}): 1.36\left(\mathrm{~m}, 8 \mathrm{H}, \mathrm{CH}_{2}\right), 2.24\left(\mathrm{t}, \mathrm{J}=6.45 \mathrm{~Hz}, 8 \mathrm{H}, \mathrm{CH}_{2}\right), 3.42\left(\mathrm{~m}, 8 \mathrm{H}, \mathrm{CH}_{2}\right), 3.70-3.85\left(\mathrm{~m}, 16 \mathrm{H}, \mathrm{Ar}-\mathrm{CH}_{2}-\mathrm{N}\right.$, $\left.\mathrm{OCH}_{2}\right), 4.20(\mathrm{t}, \mathrm{J}=7.87 \mathrm{~Hz}, 4 \mathrm{H}, \mathrm{OH}), 4.33(\mathrm{t}, \mathrm{J}=5.42 \mathrm{~Hz}, 4 \mathrm{H}, \mathrm{CH}), 4.89\left(\mathrm{dd}, \mathrm{J}=9.35 \mathrm{~Hz}, 8 \mathrm{H}, \mathrm{Ar}_{-} \mathrm{CH}_{2}-\mathrm{O}\right), 7.19-7.26(\mathrm{~m}$, $20 \mathrm{H}, \mathrm{Ph}-\mathrm{H}), 7.41$ (s, $4 \mathrm{H}, \mathrm{Ar}-\mathrm{H}), 7.64$ (s, 4H, Ar-OH); ${ }^{13} \mathrm{C}$ NMR: $(100 \mathrm{MHz}, 298 \mathrm{~K}$ in [D6]DMSO) $\delta(\mathrm{ppm})=29.3,31.0$, $31.1,45.3,54.8,60.5,107.4,122.6-128.5,138.1,147.9,149.6$.

$N$-Benzyl ammonium resorcinarene chloride (9): Tetrabenzoxazine 8 (1.0 g, $0.803 \mathrm{mmol}), 3 \mathrm{~mL}$ concentrated $\mathrm{HCl}$ (37\%), $4 \mathrm{ml} \mathrm{H} 2 \mathrm{O}, 50 \mathrm{ml}$ isopropanol. $N$-Benzyl ammonium resorcinarene chloride 9 ( $0.95 \mathrm{~g}, 88 \%)$. m.p. $>300{ }^{\circ} \mathrm{C}$; HRMS (ESI-TOF) $\mathrm{m} / \mathrm{z}$ calcd for $\mathrm{C}_{72} \mathrm{H}_{85} \mathrm{~N}_{4} \mathrm{O}_{12}$ [9-4Cl-3H] ${ }^{+}$1197.6159, Found 1197.6178, (-1.6 ppm). ${ }^{1} \mathrm{H}$ NMR (500 MHz, 298K in $\left.\left[\mathrm{D}_{6}\right] \mathrm{DMSO}\right) \delta(\mathrm{ppm}): 1.37\left(\mathrm{~m}, 8 \mathrm{H}, \mathrm{CH}_{2}\right), 2.32\left(\mathrm{~m}, 8 \mathrm{H}, \mathrm{CH}_{2}\right), 3.46\left(\mathrm{t}, \mathrm{J}=6.58 \mathrm{~Hz}, 8 \mathrm{H}, \mathrm{CH}_{2}\right), 3.98\left(\mathrm{br}, 8 \mathrm{H}, \mathrm{NCH}_{2} \mathrm{Ph}\right), 4.14$ (br, $\left.8 \mathrm{H}, \mathrm{ArCH}_{2} \mathrm{~N}\right), 4.31(\mathrm{t}, \mathrm{J}=7.57 \mathrm{~Hz}, 4 \mathrm{H}, \mathrm{CH}), 7.38(\mathrm{~m}, 12 \mathrm{H}, \mathrm{Ph}-\mathrm{H}), 7.56(\mathrm{~m}, 8 \mathrm{H}, \mathrm{Ph}-\mathrm{H}), 7.64(\mathrm{~m}, 4 \mathrm{H}, \mathrm{Ar}-\mathrm{H}), 9.05$ (br, $\left.8 \mathrm{H}, \mathrm{NH}_{2}\right), 9.44$ (br, 8H, Ar-OH); ${ }^{13} \mathrm{C}$ NMR: $\left(126 \mathrm{MHz}, 298 \mathrm{~K}\right.$ in $\left.\left[\mathrm{D}_{6}\right] \mathrm{DMSO}\right) \delta(\mathrm{ppm})=25.8,29.2,31.3,34.5,41.0,50.6$, $60.7,109.3,126.4,126.8,128.9,129.2,130.4,131.9,150.5$.

Synthesis of N-methylcarbonylmethyl-4-,4'-bipyridinium chloride (12). A flask was flame dried and back filled with nitrogen. $1.72 \mathrm{~g}(11 \mathrm{mmol})$ of 4,4'-bipyridyl were added to this and dissolved in $22 \mathrm{~mL}$ of dry THF. $3.6 \mathrm{~mL}$ (44 mmol) of chloroacetone were added and the solution was stirred at room temperature overnight. The solvent was removed under reduced pressure, yielding $2.08 \mathrm{~g}\left(76 \%\right.$ ) of $\mathbf{1 2}$. HRMS (ESI-TOF) $\mathrm{m} / \mathrm{z}$ calcd for $\mathrm{C}_{13} \mathrm{H}_{13} \mathrm{~N}_{2} \mathrm{O}[\mathbf{1 2}+\mathrm{H}]^{+} 213.1022$, Found 213.1020, (1.3 ppm). ${ }^{1} \mathrm{H}$ - and ${ }^{13} \mathrm{C}-\mathrm{NMR}$ spectra were obtained in $\mathrm{D}_{2} \mathrm{O}$ and $\left[\mathrm{D}_{6}\right]$-DMSO. ${ }^{1} \mathrm{H}$ NMR $(400 \mathrm{MHz}, 298 \mathrm{~K}$ in 
$\left.\left[\mathrm{D}_{6}\right]-\mathrm{DMSO}\right) \delta(\mathrm{ppm}): 2.34\left(\mathrm{~s}, 3 \mathrm{H}, \mathrm{CH}_{3}\right), 5.95\left(\mathrm{~s}, 2 \mathrm{H}, \mathrm{CH}_{2}\right), 8.06\left(\mathrm{~d}, \mathrm{~J}=6.16,2 \mathrm{H}, \mathrm{CH}_{2}\right), 8.71(\mathrm{~d}, \mathrm{~J}=6.88,2 \mathrm{H}, \mathrm{ArH}), 8.86(\mathrm{~d}$, $\mathrm{J}=6.12 \mathrm{~Hz}, 2 \mathrm{H}, \mathrm{ArH}), 9.11(\mathrm{~d}, \mathrm{~J}=6.92 \mathrm{~Hz}, 2 \mathrm{H}, \mathrm{ArH}) ;{ }^{13} \mathrm{C} \mathrm{NMR}:(100 \mathrm{MHz}, 298 \mathrm{~K}$ in [D6]-DMSO $\delta(\mathrm{ppm})=27.6,68.2$, $122.4,125.4,146.8,151.4$.

Synthesis of N-methyl-N'-methylcarbonylmethyl-4,4'-bipyridinium dihalide (13). $18.10 \mathrm{~g}$ (61 mmol) of 11 were dissolved in $400 \mathrm{~mL}$ of acetonitrile. $4.45 \mathrm{~mL}(61 \mathrm{mmol})$ of chloroacetone were added and the solution was refluxed overnight, producing a light brown precipitate. The solid was filtered out and dried under reduced pressure to yield $15.47 \mathrm{~g}$ $(73 \%)$ of 11. HRMS (ESI-TOF) $\mathrm{m} / \mathrm{z}$ calcd for $\mathrm{C}_{14} \mathrm{H}_{16} \mathrm{~N}_{2} \mathrm{O}$ [13-Cl-I] $]^{2+} 114.0626$ (228.1252 u), Found 114.0629 , (3.01 ppm). ${ }^{1} \mathrm{H}$ - and ${ }^{13} \mathrm{C}-\mathrm{NMR}$ spectra were obtained in $\mathrm{D}_{2} \mathrm{O}$ and $\left[\mathrm{D}_{6}\right]$-DMSO. ${ }^{1} \mathrm{H}$ NMR (400 MHz, $298 \mathrm{~K}$ in [D6]-DMSO) $\delta$ (ppm): $2.36\left(\mathrm{~s}, 3 \mathrm{H}, \mathrm{CH}_{3}\right), 4.47\left(\mathrm{~s}, 3 \mathrm{H}, \mathrm{CH}_{3}\right), 5.98\left(\mathrm{~s}, 2 \mathrm{H}, \mathrm{CH}_{2}\right), 8.82(\mathrm{~d}, \mathrm{~J}=6.80,2 \mathrm{H}, \mathrm{ArH}), 8.89$ (d, J=6.84, 2H, ArH), 9.23 $(\mathrm{d}, \mathrm{J}=6.76 \mathrm{~Hz}, 2 \mathrm{H}, \mathrm{ArH}), 9.35$ (d, J=6.72 Hz, 2H, ArH); ${ }^{13} \mathrm{C}$ NMR: $\left(100 \mathrm{MHz}, 298 \mathrm{~K}\right.$ in $\left.\left[\mathrm{D}_{6}\right]-\mathrm{DMSO}\right) \delta(\mathrm{ppm})=27.6,48.4$, $68.7,126.6,147.1,147.3$.

\section{ASSOCIATED CONTENT}

\section{Supporting Information}

The Supporting Information is available free of charge on the ACS Publications website at http://pubs.acs.org.

Experimental details, copies of the ${ }^{1} \mathrm{H}$ and ${ }^{13} \mathrm{C}$ NMR, NMR and fluorescence spectroscopy, ITC details, and Mass Spectrometry (PDF).

X-ray crystallographic data. CCDC 1525501-1525503 for 11, 11b and 13, respectively contains the supplementary crystallographic data for this paper and can be obtained free of charge from the Cambridge Crystallographic Data Centre via www.ccdc.cam.ac.uk/data request/cif.

\section{AUTHOR INFORMATION}

\section{Corresponding Authors}

E-mail: kodiah.beyeh@aalto.fi

E-mail: anslyn@austin.utexas.edu

E-mail: kari.t.rissanen@,jyu.fi

\section{ORCID}

Ngong Kodiah Beyeh: 0000-0003-3935-1812

Eric Anslyn: 0000-0002-5137-8797

Kari Rissanen: 0000-0002-7282-8419

\section{Author Contributions}

The manuscript was written through contributions of all authors.

\section{Notes:}

The authors declare no competing financial interest.

\section{ACKNOWLEDGMENTS}

The authors gratefully acknowledge financial support from the Academy of Finland (KR: grant nos. 265328, 263256 and 292746; NKB: grant no. 258653, RHAR: grant no. 272579, EK: grants 284562 and 278743), Aalto University, the University of Jyvaskyla, Finland, Central China Normal University and National Science Foundation (EVA: grant CHE-1212971), and the Welch Regents Chair (EVA: F-0046).

\section{REFERENCES}

(1) Conn, M. M.; Rebek, J. Chem. Rev. 1997, 97 (5), 1647-1668.

(2) Prins, L. J.; Reinhoudt, D. N.; Timmerman, P. Angew. Chem. Int. Ed. 2001, 40 (13), 2382-2426.

(3) Sun, X.; James, T. D. Chem. Rev. 2015, 115 (15), 8001-8037.

(4) Palacios, M. A.; Nishiyabu, R.; Marquez, M.; Anzenbacher, P. 2007, No. 11, 7538-7544.

(5) Huang, J.; Wu, Y.; Chen, Y.; Zhu, Z.; Yang, X.; Yang, C. J.; Wang, K.; Tan, W. Angew. Chem. Int. Ed. 2011, 50 (2), 401-404.

(6) Garnett, G. A. E.; Daze, K. D.; Peña Diaz, J. A.; Fagen, N.; Shaurya, A.; Ma, M. C. F.; Collins, M. S.; Johnson, D. W.; Zakharov, L. N.; Hof, F. Chem. Commun. 2016, 52 (13), 2768-2771.

(7) Rekharsky, M. V; Inoue, Y. Chem. Rev. 1998, 98 (5), 1875-1918.

(8) Engeldinger, E.; Armspach, D.; Matt, D. Chem. Rev. 2003, 103 (11), 4147-4174.

(9) Dodziuk, H. Cyclodextrins and Their Complexes; Dodziuk, H., Ed.; Wiley-VCH Verlag GmbH \& Co. KGaA: 
Weinheim, 2006.

(10) Villalonga, R.; Cao, R.; Fragoso, A. Chem. Rev. 2007, 107 (7), 3088-3116.

(11) Jordan, J. H.; Gibb, B. C. Chem. Soc. Rev. 2015, 44 (2), 547-585.

(12) Gibb, C. L. D.; Gibb, B. C. J. Am. Chem. Soc. 2004, 126 (37), 11408-11409.

(13) Gadgil, B.; Damlin, P.; Viinikanoja, A.; Heinonen, M.; Kvarnström, C. J. Mater. Chem. A 2015, 3, 9731-9737. Gao, L.; Zheng, G.; Zhou, Y.; Jiang, J.; Ding, G.; Wang, Y. Soft Mater. 2014, 12 (2), 149-158.

Sampanthar, J. T.; Neoh, K. G.; Ng, S. W.; Kang, E. T.; Tan, K. L. Adv. Mater. 2000, 12 (20), 1536-1539.

Monk, P.; Mortimer, R.; Rosseinsky, D. 2007, 2007, 483.

Kaifer, A. E. Acc. Chem. Res. 2014, 47 (7), 2160-2167.

(18) Nijhuis, C. a.; Ravoo, B. J.; Huskens, J.; Reinhoudt, D. N. Coord. Chem. Rev. 2007, 251 (13-14 SPEC. ISS.), 17611780 .

(19) Yu, G.; Zhou, X.; Zhang, Z.; Han, C.; Mao, Z.; Gao, C.; Huang, F. J. Am. Chem. Soc. 2012, 134, 19489-19497.

(20) Guo, D.-S.; Liu, Y. Acc. Chem. Res. 2014, 47, 1925-1934.

(21) Hong, M.; Zhang, Y.-M.; Liu, Y. J. Org. Chem. 2015, 80 (3), 1849-1855.

(22) Su, X.; Hu, R.; Li, X.; Zhu, J.; Luo, F.; Niu, X.; Li, M.; Zhao, Q. Inorg. Chem. 2016, 55 (2), 745-754.

(23) Altunay, N.; G??rkan, R.; Sertakan, K. Food Anal. Methods 2015, 1, 2094-2106.

(24) Xu, G.; Wu, H.; Liu, X.; Feng, R.; Liu, Z. Dye. Pigment. 2015, 120, 322-327.

(25) Zhang, Q.; Zhang, Y.; Ding, S.; Zhang, H.; Feng, G. Sensors Actuators, B Chem. 2015, 211, 377-384.

(26) Shivanyuk, A.; Spaniol, T. P.; Rissanen, K.; Kolehmainen, E.; Böhmer, V. Angew. Chem. Int. Ed. 2000, 39 (19), $3497-$ 3500 .

(27) Beyeh, N. K.; Cetina, M.; Löfman, M.; Luostarinen, M.; Shivanyuk, A.; Rissanen, K. Supramol. Chem. 2010, 22 (1112), 737-750.

(28) Pan, F.; Beyeh, N. K.; Rissanen, K. J. Am. Chem. Soc. 2015, 137 (32), 10406-10413.

(29) Pan, F.; Beyeh, N. K.; Rissanen, K. RSC Adv. 2015, 5 (71), 57912-57916.

(30) Beyeh, N. K.; Ala-Korpi, A.; Pan, F.; Jo, H. H.; Anslyn, E. V.; Rissanen, K. Chem. Eur. J. 2015, 21 (26), $9556-9562$.

(31) Beyeh, N. K.; Valkonen, A.; Bhowmik, S.; Pan, F.; Rissanen, K. Org. Chem. Front. 2015, 2 (4), $340-345$.

(32) Beyeh, N. K.; Pan, F.; Rissanen, K. Angew. Chem. Int. Ed. 2015, 54 (25), 7303-7307.

(33) Beyeh, N. K.; Pan, F.; Ras, R. H. A. Asian J. Org. Chem. 2016, 5 (8), 1027-1032.

(34) Park, Y. S.; Lee, E. J.; Chun, Y. S.; Yoon, Y. D.; Yoon, K. B. J. Am. Chem. Soc. 2002, 124 (24), $7123-7135$.

(35) Gibb, B. C.; Chapman, R. G.; Sherman, J. C.; Soc, D. J. J. A. C. 1996, No. 8, 1505-1509.

(36) Schmidt, C.; Straub, T.; Falàbu, D.; Paulus, E. F.; Wegelius, E.; Kolehmainen, E.; Bohmer, V.; Rissanen, K.; Vogt, W. Eur. J. Org. Chem. 2000, 3937-3944.

(37) Kodiah Beyeh, N.; Valkonen, A.; Rissanen, K. Org. Lett. 2010, 12 (7), 1392-1395.

(38) Pan, F.; Beyeh, N. K.; Ras, R. H. A.; Rissanen, K. CrystEngComm 2016, 18 (30), 5724-5727.

(39) Freitag, M.; Gundlach, L.; Piotrowiak, P.; Galoppini, E. J. Am. Chem. Soc. 2012, 134 (7), 3358-3366.

(40) Bhasikuttan, A. C.; Mohanty, J.; Nau, W. M.; Pal, H. Angew. Chem. Int. Ed. 2007, 46 (22), 4120-4122.

(41) Tunstad, L. M.; Tucker, J. A.; Dalcanale, E.; Weiser, J.; Bryant, J. A.; Sherman, J. C.; Helgeson, R. C.; Knobler, C. B.; Cram, D. J. J. Org. Chem. 1989, 54 (6), 1305-1312. 